\title{
PRODUCT DEVELOPMENT IN THE ICT INDUSTRY: CRITICAL ENABLERS OF CUSTOMER SATISFACTION
}

\author{
A. Naicker ${ }^{1}$, S. Naidoo ${ }^{1 *} \&$ A. Rajcoomar ${ }^{1}$
}

\section{ARTICLE INFO}

Article details

Presented at the $32^{\text {nd }}$ annual conference of the Southern African Institute for Industrial Engineering (SAIIE), held from 4-6 October 2021 in Muldersdrift, South Africa.

Available online $\quad 29$ Nov 2021

\section{Contact details}

Corresponding author naidoosu@unisa.ac.za

Author affiliations

1 Department of Operations Management, University of South Africa, South Africa

\section{ORCID® identifiers}

A.Naicker

https://orcid.org/0000-0002-0066-6983

S. Naidoo

https://orcid.org/0000-0003-4284-516X

A. Rajcoomar

https://orcid.org/0000-0002-4730-4912

\section{DOI}

http: //dx.doi.org/10.7166/32-3-2623
ABSTRACT

Because of the recent introduction of several touchpoints that place purchasing power completely in the customer's hands, product development directly impacts how a customer experiences an organisation. The purpose of this study was to identify a course of action to overcome the factors affecting customer experience during product development. The research setting was a leading telecommunications firm in South Africa. A quantitative approach was undertaken through an online survey questionnaire. A sample of 120 individuals participated in the study. The findings indicate that system capacity takes precedence over customers. There also appear to be concerns with the significance of the roles of change management, customer experience, and project management functions in product development. It is stressed that customers need to be more actively involved, that an efficient change management tool should be adopted and socialised, and that the principles of the strategic transformation programme management process should be considered.

\section{OPSOMMING}

Die onlangse bekendstelling van verskeie raakpunte wat die koopkrag direk in die koper se hande plaas het daartoe gelei dat produkontwikkeling ' $n$ direkte impak op 'n kliënt se ervaring van 'n maatskappy het. Die doel van hierdie studie is om ' $n$ plan van aksie te identifiseer om die faktore wat ' $n$ kliënt se tevredenheid beïnvloed te verbeter. 'n Groot Suid-Afrikaanse telekommunikasie maatskappy is as gevallestudie gebruik. 'n Kwantitatiewe benadering is gevolg deur middel van 'n aanlyn vraelys. 120 individue het aan die opname deelgeneem. Die bevindinge dui daarop dat stelselkapasiteit voorkeur oor kliënte geniet. Dit blyk ook dat daar bekommernis is oor die belangrikheid van die rolle van veranderingsbestuur, kliënte ervaring, en projekbestuur in produkontwikkeling. Daar word beklemtoon dat kliënte meer aktief betrek moet word en dat ' $n$ doeltreffende veranderingsbestuur werkstuk aanvaar en versprei moet word. Die beginsels van die strategiese transformasie program bestuursplan moet ook oorweeg word.

With the emergence of the internet and online communication technologies, the ways in which customers might be involved in such design activities have changed beyond recognition over the last 20 years [1]. Customer experience has become a critical element owing to the recent introduction of several internet touchpoints that place purchasing power completely in the hands of the consumer. Product development has a direct impact on customers' experiences and their perceptions of an organisation. Failure to produce products that can enhance an excellent customer experience will ultimately affect the market share of an organisation. This is because customers are willing to remain loyal to organisations that respond to their needs [2].

Products and services are the heart and soul of most businesses [2]. In this study, the researchers describe the salient features of product development and the impact they have on the experience that customers have when using an organisation's products and services. This research allows for a deeper dive into the life of a product, from conception to implementation. 
Brainstorming and qualitative and quantitative research studies produce an excellent product concept that is suited to customer needs; however, by the time it reaches the market, it has only a vague resemblance to what it was intended to be [3]. These inefficiencies cause customer frustration and a poor customer experience [3]. The research problem that is investigated within the ambit of this research study reads:

The identification of the factors of product development in a leading information, communication, and technology (ICT) organisation that negatively affect customer experience.

\section{THEORETICAL FRAMEWORK}

In a time of economic challenges, competition is heightened, cost-saving measures are implemented, and change is imminent. Increased pressure develops for ICT companies to deliver on innovative products and an excellent customer experience. Transformation is required to stay ahead of the competition [4].

\subsection{Product development}

Long before a customer unpacks a new product, a version of that product was visualised by a designer or developer [4]. Historically, when organisations instigated a new product development project, they would begin with research and development. The concepts worked on and sent to engineering, leaves the final product significantly changed [5]. Chyne [6] agrees that, unless tried and tested, a concept is unlikely to become a product.

Market and industry internationalisation first seen in the 1980s, when the rise of global products and similar product conceptions and segments gave birth to stronger competitiveness [4]. By the 1990s, the role of product development had moved beyond just curiosity and excitement to become a crucial focus of industrial competition. The development of products needed to be faster, more efficient, and more effective in order to address competitiveness. It is now evident that proper design and development have a massive influence on competitive advantage, on cost, and ultimately on customer satisfaction. Clark and Fujimoto [4] alluded to the fact that an organisation's product strategy and how it manages product development will determine its performance in the market. The steps taken during product development (quality of work, speed, and efficiency) will determine the product's competitiveness. The definitions of products (tangible) and services (intangible) are becoming more and more distorted. A product can now be tangible, or intangible, or both [7]. According to Amue and Adiele [8], new product development is required to develop original products or to make improvements and modifications. Product development is the transformation of market opportunity and technology assumptions into marketable products [9].

\subsection{Product development process}

The product development process occurs between the idea and the usability phases. Glessner and Gillis [10] agree but exclude the development process. They go on to define the development process as where the product planning occurs, the feasibility study happens, and the product is built and readied for introduction to the market. Bhuiyan [11] agrees, listing the stages in Figure 1. It is also mentioned that the product must be assessed and reassessed with the conceptual decision in mind, and the outcome should determine whether to begin with its development or with its introduction to the market.

Idea generation allows for the innovation of several ideas from either internal or external sources. Idea screening and evaluation assesses and narrows down the valuable or profitable products. Business analysis and testing explain product ideas while exposing weaknesses, resources, and technologies. Testing could include customer focus groups [8]. Marketing strategy development encompasses the end-to-end design of the marketing strategy. Business analysis determines whether the financial goals of the organisation will be met. This includes the analysis of cost, sales, profit projection, and financial feasibility. Product development is where the actual product will materialise via prototyping and testing if all the elements of the concept are achieved. Commercialisation makes the product available to customers via marketing scheme [13]. 


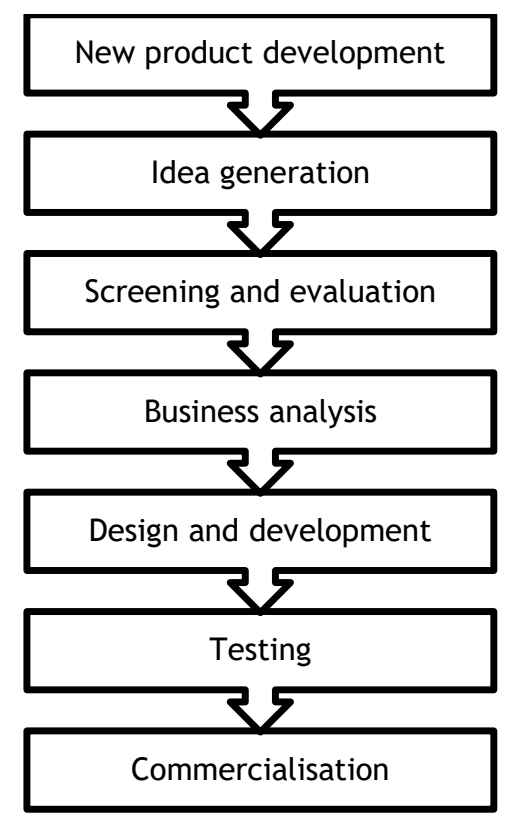

Figure 1: Stages of new product development

\subsection{The information, communication, and technology sector}

Historically, the ICT sector relied on postal, telephone, and telegraph services to transfer information. These were predominantly fixed-line based, and mostly owned and managed by the government [14]. Celebic and Rendulic [15] concur, and add that, in the 21st century, ICT is the underpinning force of economic and social change. Computers and associated end-user devices with internet access have removed the distance barrier between the sender and the receiver of information. ICT increases proficiencies and production [14]. ICT also provides easier access to products, services, data, and marketplaces, and enables competencies in business by assisting with competitiveness, market expansion, and environmental matters [16]. Technology is, on the one hand, the product of people and, on the other hand, their producer [17]. Furthermore, the demand for benefits are high, and if the right enhancements are put in place, the demand will increase [14]. These enhancements are content, connectivity, expertise, support, and a supportive policy framework. Kodama [16] elaborates that ICT on its own does not sustain competitiveness; it also requires innovation, knowledge, and skills in order to be developed further. With the introduction of products such as Apple's iPod, iPhone, and iPad, and Google's Android software, it has become essential for organisations to focus on generating new business models and to incorporate ICT innovation into their corporate product strategy. Detecon International $\mathrm{GmbH}$ [18] adds that increasing product convergence and the shift of business models, along with customer expectations, have given birth to product, processes, and information technology (IT) complexities that result in product portfolios becoming more diverse. Gillwald, Moyo and Stork [19] state that the ICT market in South Africa is structured around several vertically unified operators. What used to be a public switched telephone network (PSTN) (landline), mobile land communications systems (mobile), value-added network service providers, and broadcasting signal distribution licences (satellite) were changed into networks, services, and content licences. In recent years, the fixed and mobile markets have seen poor service, price matching, and anti-competitiveness. This has created highly competitive pressure from new players in both markets.

\subsection{Product failure/success}

Syeda [20] explains that it is not an uncommon occurrence around the world for new products to fail in the market. Grabowski [21] elaborates that between 30 and 45 per cent of new products are not profitable. This is the result of weak markets and/or poor product placement, a failure to address customers' requirements, and a dearth of internal skills. Loch and Kavadias [22] mention that the downfall of a product can be the result of weak judgement. Products might be taken to development too early, causing cost escalations and offsetting the time and resources input. In general, according to Berry [23], a product failure occurs when its presence in the market leads to its removal because of its inability to attain essential market share, its failure to realise the company's set life cycle, and its unprofitability. Wig [24] says that a product is successful if it is profitable and if customers are satisfied using it. Understanding how potential users accept a new technology has been the focus of many studies over the past 20 years [25]. The common 
reasons behind product failure are the inability to adopt market positioning in product innovation, a dearth of market research, and omitting the customer from product development.

\subsection{Change and its impact on product development}

Figliomeni [26] states that, in order to develop current processes or implement different processes, a change manager needs to be aware of the current state of the process, as in Figure 2.

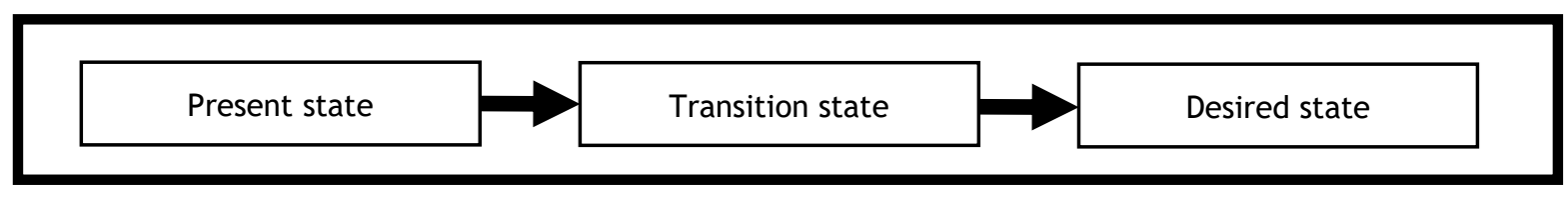

Figure 2: Change state phases

The change manager must also define what steps are required to reach the required state. Change management is an organised method of ensuring the comprehensive and efficient implementation of change. It focuses on individuals and teams that shift from the present state to a desired state [27]. The Management Learning Center [28] and Hayes [29] agree that planning, reviewing progress, sustaining, and learning are required during the steps to change. Passenheim [30] mentions that there are several models of change. Prioritising change is based on an organisation's main objective, and this can be used when selecting a model [31, 32]..

According to Gagnon [33], a change leader must reveal to all role players that the current way of working is not sustainable. They would need to create a vision of what the future will look like, establish a team that is willing to lead the change, solicit broad organisational support, and make a noise about early victories to celebrate wins. Steyn and Schmikl [2] suggest Lewin's three-step process (Figure 3) for successful change. This involves unfreeze the existing levels of behaviour and moving to a new level, and then refreezing the behaviour at this new level. According to Steyn and Schmikl [2], 'unfreezing' means motivating change while supporting the existing culture. During this process, possible issues regarding employees should be considered and mitigated against to restore balance while the change is being accepted.

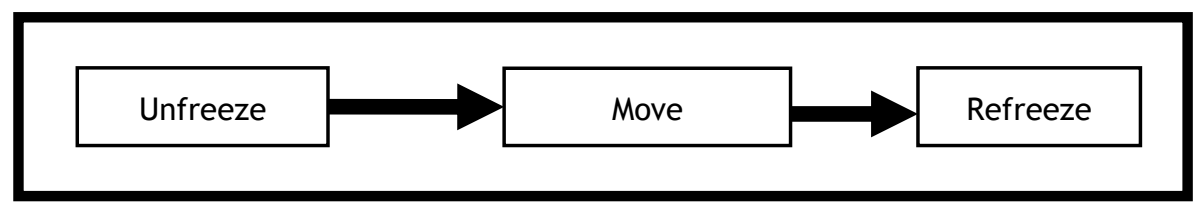

Figure 3: Lewin's three-step process

Changing involves catering for new operating models by facilitating the change with the use of advisers, training instruments, and tools. Refreezing involves stabilising the change and assisting employees to incorporate it into their culture. This could be done with the aid of coaching and mentoring.

\subsection{Customer experience and the role it plays in product development}

Clark and Fujimoto [4] argue that 'product development' is a rehearsal of 'customer product experiences'. They believe that the analysis of product development and customer behaviour can be done simultaneously. As customer behaviour changes, so does the development design. Matching customer patterns with development is a critical action for product development [8, 11] to concur. Pairing this understanding with the experiences that customers most value delivers winning products, removes hindrances, and creates great value propositions. Immonen and Saaksvuori [34] allude to the fact that customers are the 'driving force' behind organisations. Nambisan [35] differs from them, feeling that innovation and a strong product concept can predict the future of customer experience. Clark and Fujimoto [4] agree that it trumps bringing customers into the development process, because customers' responses are not an accurate prediction of how the market will react.

\subsection{Project management and the role it plays in product development}

Product development is instrumental in driving organisations, especially those that invest significantly in research and development, since only a small number of products make it into the market. This is where project management comes into play. It can be used to flag products that need to be shut down to avoid unnecessary costs; it can drive efficiencies and effectiveness; and it can be used to assist an organisation 
to stay competitive and to reveal resource issues [32]. According to Stoneburner [36], it not only speeds up product development, but is also fundamental in the construction of an organisation's development proficiencies and learning.

This abbreviated literature review has focused on all of the factors to do with product development success or failure.. Long before the introduction of a product into the market, development needs to occur. The steps taken during product development (quality of work, speed, and efficiency) will drive the product's competitiveness [4]. An organisation's product strategy and how it manages development will determine the product's performance in the market

\section{RESEARCH APPROACH}

A case study approach was selected as the research design for this investigation into the identified problem being solved in this organisation, as it is work-practice-based. According to Watkins [37], "a case study research is an empirical enquiry that investigates a contemporary phenomenon within its real-life context ...". Watkins [37] and Kothari [38] describe research as a scientific study and a methodical hunt for relevant facts or understanding of a subject, with the purpose of finding solutions. It entails a process of enquiringly observing working conditions both judgementally and logically in order to obtain knowledge of their foundation, significance, efficiencies, and competencies.

The purpose of this research study is to identify the factors impacting product development that affect customer experience but limited to the company being studied. As this research is focused on a specific outcome, 'applied research' serves as a research type that is used to enhance practices and policies with the aid of current knowledge [37]. Kothari [38] states that the goal of using applied research is to discover ways to resolve immediate issues experienced by organisations. The research is executed in the 'social world', since it involves the systems in which people operate. According to Watkins [37], social scientists attempt to comprehend why people do what they do by trying to understand the systems they work in.

This research is empirical in nature and focuses on a work-context-based problem in the sponsoring organisation. Watkins [37] argues that, for a researcher to understand the problem to be investigated, they also need to take a theoretical stance. The 'positivistic' paradigm serves as the basis for this study, as it attempts to investigate a research problem by testing whether the theoretically derived hypotheses hold true for the situation investigated. A quantitative approach will be used, as the research involves "looking at large amounts of one or more variables of interest" [37, 38]. The research study follows the action research method, which, according to Watkins [37], can be applied to quantitative research paradigms.

The target population aiding this study is product-focused and consists of individuals who form part of the product process [37, 38]. A sample design is a set plan before any data is gathered for procuring a sample from a set population. Selecting a representative sub-set of observations from a population to determine the characteristics of the random variables being studied is necessary [37, 38]. When selecting a sampling method for a research study, a choice must be made between the category's probability and non-probability sampling. Probability sampling is used when the researcher can determine in advance that each segment of the population is represented in the sample being drawn. Non-probability sampling is used when the researcher has no way of forecasting or ensuring that each element of the population is represented in the sample. Watkins and Kothari [37, 38] state that non-probability samples do not allow the researcher to determine the elements that have a known probability. Thus, a decision must be taken to select one's sample using one of the following three methods: convenience sampling, quota sampling, or judgement (purposive) sampling. Watkins [37] agrees, and states that a survey is the gathering of a large amount of data that will be converted into numeric form, usually with the use of a questionnaire. It will help to derive the existing position of a population in respect of the variables.

A sample size of 120 product personnel in the information, communication, and technology section (ICT) of the organisation was drawn for this research, using the non-probability judgement sampling method.

\subsection{Data collection}

A survey was selected as the data collection methodology to collect data from specialists and managers to discover their views about how the factors impacting product development affect customer experience. Individuals - specialists and managers - served as the unit of analysis.

Close-ended statements were posed in the questionnaire, giving the population an option to rate the statements on a scale of 1 to 5 , with 1 being 'strongly disagree' and 5 being 'strongly agree'. The aim of 
this data collection process was to understand whether the product development process included efficient project management practices and the customer's voice, and whether all the roles that people play are considered when change occurs.

\subsection{Questionnaire design}

The questionnaire was composed of 34 close-ended statements and required participants to express their opinions by rating all of the statements. The questionnaire was based on a five-point Likert scale. The questionnaire was sent out using Quest Back (https://response.questback.com). The survey consisted of an introductory covering letter and questions.

Table 1: Frequency distribution of factors impacting the development of products

\begin{tabular}{|c|c|c|c|c|c|c|}
\hline \multirow[t]{2}{*}{$\#$} & \multirow[t]{2}{*}{ Question } & $\begin{array}{l}\text { Strongly } \\
\text { disagree }\end{array}$ & $\begin{array}{l}\text { Somewhat } \\
\text { disagree }\end{array}$ & Neutral & $\begin{array}{l}\text { Somewhat } \\
\text { agree }\end{array}$ & $\begin{array}{l}\text { Strongly } \\
\text { agree }\end{array}$ \\
\hline & & 1 & 2 & 3 & 4 & 5 \\
\hline \multirow{2}{*}{ A } & \multirow{2}{*}{$\begin{array}{l}\text { Factors impacting the development } \\
\text { of products }\end{array}$} & 0 & 5 & 75 & 32 & 8 \\
\hline & & $0 \%$ & $4 \%$ & $63 \%$ & $27 \%$ & $7 \%$ \\
\hline \multirow{2}{*}{ Q1 } & \multirow{2}{*}{$\begin{array}{l}\text { My organisation has excellent products } \\
\text { development skills. }\end{array}$} & 1 & 19 & 35 & 44 & 21 \\
\hline & & $1 \%$ & $16 \%$ & $29 \%$ & $37 \%$ & $18 \%$ \\
\hline \multirow{2}{*}{ Q2 } & \multirow{2}{*}{$\begin{array}{l}\text { My organisation always delivers } \\
\text { products customers want. }\end{array}$} & 4 & 23 & 49 & 33 & 11 \\
\hline & & $3 \%$ & $19 \%$ & $41 \%$ & $28 \%$ & $9 \%$ \\
\hline \multirow[b]{2}{*}{ Q3 } & \multirow{2}{*}{$\begin{array}{l}\text { Product specifications are manipulated } \\
\text { and built based on my organisation } \\
\text { system capabilities. }\end{array}$} & 4 & 12 & 30 & 53 & 21 \\
\hline & & $3 \%$ & $10 \%$ & $25 \%$ & $44 \%$ & $18 \%$ \\
\hline \multirow{2}{*}{ Q4 } & \multirow{2}{*}{$\begin{array}{l}\text { Product prioritisation is based on IT } \\
\text { capacity. }\end{array}$} & 3 & 13 & 26 & 39 & 39 \\
\hline & & $3 \%$ & $11 \%$ & $22 \%$ & $33 \%$ & $33 \%$ \\
\hline \multirow{2}{*}{ Q5 } & \multirow{2}{*}{$\begin{array}{l}\text { Customers are consulted throughout } \\
\text { the product development process. }\end{array}$} & 14 & 36 & 40 & 18 & 12 \\
\hline & & $12 \%$ & $30 \%$ & $33 \%$ & $15 \%$ & $10 \%$ \\
\hline \multirow{2}{*}{ Q6 } & \multirow{2}{*}{$\begin{array}{l}\text { My organisation follows a strict } \\
\text { product development process. }\end{array}$} & 1 & 21 & 28 & 48 & 22 \\
\hline & & $1 \%$ & $18 \%$ & $23 \%$ & $40 \%$ & $18 \%$ \\
\hline \multirow{2}{*}{ Q7 } & \multirow{2}{*}{$\begin{array}{l}\text { Product development is without major } \\
\text { issues on the IT systems (OSS/BSS). }\end{array}$} & 25 & 36 & 30 & 22 & 7 \\
\hline & & $21 \%$ & $30 \%$ & $25 \%$ & $18 \%$ & $6 \%$ \\
\hline \multirow{2}{*}{ Q8 } & \multirow{2}{*}{$\begin{array}{l}\text { My organisation's Product Houses } \\
\text { duplicate product development work. }\end{array}$} & 7 & 29 & 43 & 31 & 10 \\
\hline & & $6 \%$ & $24 \%$ & $36 \%$ & $26 \%$ & $8 \%$ \\
\hline
\end{tabular}

Table 2: Frequency distribution of change management impact on product development

\begin{tabular}{|c|c|c|c|c|c|c|}
\hline \multirow[t]{2}{*}{$\#$} & \multirow[t]{2}{*}{ Question } & $\begin{array}{l}\text { Strongly } \\
\text { disagree }\end{array}$ & $\begin{array}{l}\text { Somewhat } \\
\text { disagree }\end{array}$ & Neutral & $\begin{array}{l}\text { Somewhat } \\
\text { agree }\end{array}$ & $\begin{array}{l}\text { Strongly } \\
\text { agree }\end{array}$ \\
\hline & & 1 & 2 & 3 & 4 & 5 \\
\hline \multirow{2}{*}{ B } & \multirow{2}{*}{$\begin{array}{l}\text { Change management impact on } \\
\text { product development }\end{array}$} & 0 & 10 & 66 & 38 & 6 \\
\hline & & $0 \%$ & $8 \%$ & $55 \%$ & $32 \%$ & $5 \%$ \\
\hline \multirow{2}{*}{ Q9 } & \multirow{2}{*}{ In my organisation change is frequent. } & 0 & 8 & 30 & 50 & 32 \\
\hline & & $0 \%$ & $7 \%$ & $25 \%$ & $42 \%$ & $27 \%$ \\
\hline \multirow{2}{*}{ Q10 } & \multirow{2}{*}{$\begin{array}{l}\text { Product Houses are taken into } \\
\text { consideration when change occurs. }\end{array}$} & 3 & 19 & 47 & 43 & 8 \\
\hline & & $3 \%$ & $16 \%$ & $39 \%$ & $36 \%$ & $7 \%$ \\
\hline \multirow[b]{2}{*}{ Q11 } & \multirow{2}{*}{$\begin{array}{l}\text { My organisation takes into } \\
\text { consideration products that are in the } \\
\text { development pipeline when making } \\
\text { change. }\end{array}$} & 6 & 25 & 42 & 39 & 8 \\
\hline & & $5 \%$ & $21 \%$ & $35 \%$ & $33 \%$ & $7 \%$ \\
\hline \multirow{2}{*}{ Q12 } & \multirow{2}{*}{$\begin{array}{l}\text { My organisation takes customers into } \\
\text { consideration when change happens. }\end{array}$} & 3 & 20 & 41 & 40 & 16 \\
\hline & & $3 \%$ & $17 \%$ & $34 \%$ & $33 \%$ & $13 \%$ \\
\hline \multirow{2}{*}{ Q13 } & \multirow{2}{*}{$\begin{array}{l}\text { Change is seamless in product } \\
\text { development. }\end{array}$} & 12 & 36 & 44 & 23 & 5 \\
\hline & & $10 \%$ & $30 \%$ & $37 \%$ & $19 \%$ & $4 \%$ \\
\hline \multirow{2}{*}{ Q14 } & \multirow{2}{*}{$\begin{array}{l}\text { My organisation has adopted an } \\
\text { efficient change management model. }\end{array}$} & 4 & 30 & 44 & 31 & 11 \\
\hline & & $3 \%$ & $25 \%$ & $37 \%$ & $26 \%$ & $9 \%$ \\
\hline \multirow{2}{*}{ Q15 } & \multirow{2}{*}{$\begin{array}{l}\text { Change is communicated proactively to } \\
\text { product developers. }\end{array}$} & 6 & 28 & 52 & 24 & 10 \\
\hline & & $5 \%$ & $23 \%$ & $43 \%$ & $20 \%$ & $8 \%$ \\
\hline \multirow{2}{*}{ Q16 } & \multirow{2}{*}{$\begin{array}{l}\text { Change in company structure effects } \\
\text { the way products are developed. }\end{array}$} & 3 & 16 & 34 & 43 & 24 \\
\hline & & $3 \%$ & $13 \%$ & $28 \%$ & $36 \%$ & $20 \%$ \\
\hline
\end{tabular}


Table 3: Frequency distribution of product development impact on customer experience

\begin{tabular}{|c|c|c|c|c|c|c|}
\hline \multirow[t]{2}{*}{$\#$} & \multirow[t]{2}{*}{ Question } & $\begin{array}{l}\text { Strongly } \\
\text { disagree }\end{array}$ & $\begin{array}{l}\text { Somewhat } \\
\text { disagree }\end{array}$ & Neutral & $\begin{array}{l}\text { Somewhat } \\
\text { agree }\end{array}$ & $\begin{array}{l}\text { Strongly } \\
\text { agree }\end{array}$ \\
\hline & & 1 & 2 & 3 & 4 & 5 \\
\hline \multirow{2}{*}{ C } & \multirow{2}{*}{$\begin{array}{l}\text { Product development impact on } \\
\text { customer experience }\end{array}$} & 0 & 8 & 71 & 38 & 3 \\
\hline & & $0 \%$ & $7 \%$ & $59 \%$ & $32 \%$ & $3 \%$ \\
\hline \multirow{2}{*}{ Q17 } & \multirow{2}{*}{$\begin{array}{l}\text { My organisation cares about its } \\
\text { customers. }\end{array}$} & 0 & 6 & 14 & 60 & 40 \\
\hline & & $0 \%$ & $5 \%$ & $12 \%$ & $50 \%$ & $33 \%$ \\
\hline \multirow{2}{*}{ Q18 } & \multirow{2}{*}{$\begin{array}{l}\text { My organisation has an actively involved } \\
\text { Customer Experience division. }\end{array}$} & 3 & 9 & 30 & 52 & 26 \\
\hline & & $3 \%$ & $8 \%$ & $25 \%$ & $43 \%$ & $22 \%$ \\
\hline \multirow{2}{*}{ Q19 } & \multirow{2}{*}{$\begin{array}{l}\text { Customer experience plays a major role } \\
\text { when products are developed. }\end{array}$} & 3 & 13 & 32 & 41 & 31 \\
\hline & & $3 \%$ & $11 \%$ & $27 \%$ & $34 \%$ & $26 \%$ \\
\hline \multirow{2}{*}{ Q20 } & \multirow{2}{*}{$\begin{array}{l}\text { Products on the system are the named } \\
\text { according to what is advertised. }\end{array}$} & 8 & 24 & 35 & 37 & 16 \\
\hline & & $7 \%$ & $20 \%$ & $29 \%$ & $31 \%$ & $13 \%$ \\
\hline \multirow{2}{*}{ Q21 } & \multirow{2}{*}{ The product ordering process is quick. } & 28 & 35 & 36 & 15 & 6 \\
\hline & & $23 \%$ & $29 \%$ & $30 \%$ & $13 \%$ & $5 \%$ \\
\hline \multirow{2}{*}{ Q22 } & \multirow{2}{*}{$\begin{array}{l}\text { Product development receives a high } \\
\text { amount of queries from customer-facing } \\
\text { staff regarding customer enquiries. }\end{array}$} & 9 & 18 & 46 & 35 & 12 \\
\hline & & $8 \%$ & $15 \%$ & $38 \%$ & $29 \%$ & $10 \%$ \\
\hline \multirow[b]{2}{*}{ Q23 } & \multirow{2}{*}{$\begin{array}{l}\text { Product development receives a high } \\
\text { amount of queries from customer-facing } \\
\text { staff trying to understand how products } \\
\text { are displayed on the organisation bill. }\end{array}$} & 7 & 19 & 48 & 40 & 6 \\
\hline & & $6 \%$ & $16 \%$ & $40 \%$ & $33 \%$ & $5 \%$ \\
\hline \multirow{2}{*}{ Q24 } & \multirow{2}{*}{$\begin{array}{l}\text { Products with after sales issues are easy } \\
\text { to fix. }\end{array}$} & 14 & 37 & 45 & 18 & 6 \\
\hline & & $12 \%$ & $31 \%$ & $38 \%$ & $15 \%$ & $5 \%$ \\
\hline \multirow[b]{2}{*}{ Q25 } & \multirow{2}{*}{$\begin{array}{l}\text { My organisation employs the use of a } \\
\text { single efficient Order Management System } \\
(\mathrm{OMS}) \text { or Customer Relationship } \\
\text { Management tool (CRM) across all their } \\
\text { products and services. }\end{array}$} & 12 & 27 & 32 & 32 & 17 \\
\hline & & $10 \%$ & $23 \%$ & $27 \%$ & $27 \%$ & $14 \%$ \\
\hline \multirow{2}{*}{ Q26 } & \multirow{2}{*}{$\begin{array}{l}\text { Strategic product roadmap is set } \\
\text { according to what South African } \\
\text { customers are ready for. }\end{array}$} & 5 & 26 & 40 & 37 & 12 \\
\hline & & $4 \%$ & $22 \%$ & $33 \%$ & $31 \%$ & $10 \%$ \\
\hline
\end{tabular}

Table 4: Frequency distribution of project management impact on product development

\begin{tabular}{|c|c|c|c|c|c|c|}
\hline \multirow[t]{2}{*}{$\#$} & \multirow[t]{2}{*}{ Question } & $\begin{array}{l}\text { Strongly } \\
\text { disagree }\end{array}$ & $\begin{array}{c}\text { Somewhat } \\
\text { disagree }\end{array}$ & Neutral & $\begin{array}{l}\text { Somewhat } \\
\text { agree }\end{array}$ & $\begin{array}{l}\text { Strongly } \\
\text { agree }\end{array}$ \\
\hline & & 1 & 2 & 3 & 4 & 5 \\
\hline \multirow{2}{*}{ D } & \multirow{2}{*}{$\begin{array}{l}\text { Project management impact on } \\
\text { product development }\end{array}$} & 1 & 14 & 56 & 39 & 10 \\
\hline & & $1 \%$ & $12 \%$ & $47 \%$ & $33 \%$ & $8 \%$ \\
\hline \multirow{2}{*}{ Q27 } & \multirow{2}{*}{$\begin{array}{l}\text { My organisation has an active Project } \\
\text { Management Office. }\end{array}$} & 2 & 16 & 32 & 42 & 28 \\
\hline & & $2 \%$ & $13 \%$ & $27 \%$ & $35 \%$ & $23 \%$ \\
\hline \multirow{2}{*}{ Q28 } & \multirow{2}{*}{$\begin{array}{l}\text { Product development employs strong } \\
\text { project management principles. }\end{array}$} & 1 & 25 & 34 & 43 & 17 \\
\hline & & $1 \%$ & $21 \%$ & $28 \%$ & $36 \%$ & $14 \%$ \\
\hline \multirow{2}{*}{ Q29 } & \multirow{2}{*}{$\begin{array}{l}\text { The IT (Information Technology) } \\
\text { project manager always delivers on the } \\
\text { product developers requirements. }\end{array}$} & 9 & 28 & 33 & 35 & 15 \\
\hline & & $8 \%$ & $23 \%$ & $28 \%$ & $29 \%$ & $13 \%$ \\
\hline \multirow[b]{2}{*}{ Q30 } & \multirow{2}{*}{$\begin{array}{l}\text { Product projects are prioritised } \\
\text { according to the Product House that } \\
\text { has the highest influence over the IT } \\
\text { division. }\end{array}$} & 7 & 15 & 46 & 37 & 15 \\
\hline & & $6 \%$ & $13 \%$ & $38 \%$ & $31 \%$ & $13 \%$ \\
\hline \multirow{2}{*}{ Q31 } & \multirow{2}{*}{$\begin{array}{l}\text { Product projects are prioritised } \\
\text { according to the most urgent customer } \\
\text { need. }\end{array}$} & 3 & 24 & 42 & 33 & 18 \\
\hline & & $3 \%$ & $20 \%$ & $35 \%$ & $28 \%$ & $15 \%$ \\
\hline \multirow{2}{*}{ Q32 } & \multirow{2}{*}{$\begin{array}{l}\text { The project life cycle is followed for all } \\
\text { product development projects. }\end{array}$} & 7 & 22 & 35 & 39 & 17 \\
\hline & & $6 \%$ & $18 \%$ & $29 \%$ & $33 \%$ & $14 \%$ \\
\hline \multirow{2}{*}{ Q33 } & \multirow{2}{*}{$\begin{array}{l}\text { My organisation's project managers are } \\
\text { excellently skilled. }\end{array}$} & 8 & 17 & 49 & 33 & 13 \\
\hline & & $7 \%$ & $14 \%$ & $41 \%$ & $28 \%$ & $11 \%$ \\
\hline \multirow{2}{*}{ Q34 } & \multirow{2}{*}{ Product projects are effectively run. } & 10 & 25 & 40 & 33 & 12 \\
\hline & & $8 \%$ & $21 \%$ & $33 \%$ & $28 \%$ & $10 \%$ \\
\hline
\end{tabular}




\subsection{Data validity and reliability}

According to Watkins [37], validity is focused on whether the research findings are an accurate representation of what is currently happening. Watkins [37] identifies three forms of validity: content validity, criterion-related validity, and construct validity. The following forms of validity were applied in this research study:

- Criterion-related validity: This is the realisation of measures used for approximation. Criterion measures must be judged on the following qualities:

- Criterion is relevant: If the criterion is defined and scored in terms of what one judges the proper measure of success.

- Freedom from bias: If the criterion gives each respondent the opportunity to score well.

- Reliability: If the criterion is stable and reproducible.

- Availability: If the information specified by the criterion is available.

- $\quad$ Content validity: This ensures that the subject matter is well-represented by the selected samples.

According to Watkins [37], "reliability also refers to trustworthiness". The findings are reliable if the results are reproduced when the research is repeated.

200 potential candidates were approached, of whom 120 responded. Middle management represented 49 per cent of the sample size; junior management made up 29 per cent; and operational staff made up 22 per cent. The perceptions of the respondents in the three categories were fairly balanced when analysing the frequency distributions

\section{RESULTS}

The captured sample data was statistically analysed and interpreted using frequency distributions and percentages linked to the Likert scale, and Cronbach's alpha test was used to test the reliability of the designed questionnaire.

\subsection{Cronbach's alpha test of reliability}

Analysing the frequency distribution of the factors impacting the development of products revealed that IT systems and capacity take precedence over the needs and wants of the customer during product development. However, given that there were several differences of opinion, further investigation is required.

- $42 \%$ of the respondents disagreed that customers are consulted throughout the product development process.

- $\quad 41 \%$ of the respondents were unsure, while $22 \%$ disagreed that the organisation always delivers the products that customers want.

- $62 \%$ of the respondents agreed that product specifications are manipulated and set on the basis of the organisation's system capabilities.

- $65 \%$ of the respondents agreed that product prioritisation is based on IT capacity.

Analysing the frequency distribution of the impact of change on product development raises some concerns: there appear to be major problems in the company's change management techniques; most either appeared not to know whether a change management model exists, or completely disagreed that there is an efficient model; and last, most agreed that changes to the company structure affect the way in which products are developed. This revealed that change is a regular occurrence; however, there may not be an efficient change management model. Overall, it appeared that there was a high amount of uncertainty among the respondents when it comes to change and its management. Such differences in perceptions require further investigation.

- $\quad 68 \%$ of the respondents agreed that change is frequent.

- $57 \%$ of the sample either disagreed or were uncertain whether the product houses are considered during change.

- $61 \%$ showed uncertainty or disagreed that products in the development pipeline are considered when change occurs.

- $53 \%$ of the respondents were either not sure or did not believe that customers are considered when change happens.

- $75 \%$ of the sample did not know, or disagreed, whether change is seamless. 
Analysing the frequency distribution of the product development that impacted on customer experience was difficult to understand, as most of the respondents perceived that customer experience plays a major role in product development. While order processing time is a crucial check point for customer experience, it is concerning that the majority (68\%) of the sample had different perceptions and were unaware that two different systems are used for products and services. There also appeared to be a problem with the role of customer experience in product development because of the high level of uncertainty. The numerous differences of opinion established by the study require further investigation.

- $\quad 83 \%$ of the respondents agreed that their organisation cares about its customers.

- $65 \%$ of the sample agreed that the organisation has an actively involved customer experience division.

- $60 \%$ of the respondents perceived that customer experience plays a major role.

- $63 \%$ of respondents perceived that customers do not get what they want.

- $82 \%$ of the sample were uncertain or disagreed that the product order processing is quick.

- $\quad 59 \%$ of the sample had different perceptions about whether the strategic product roadmap is set according to what South African customers are ready for.

- $80 \%$ of the sample had different perceptions about whether products with after-sales issues are easy to fix.

Analysing the frequency distribution of the project management impact on product development established that differences of opinion require further investigation.

- $58 \%$ agreed that the organisation has an active project management office.

- $50 \%$ of the respondents agreed that product development employs strong project management principles.

- $\quad 57 \%$ of the sample had different perceptions about whether product projects are prioritised according to the product house that has the highest influence over the IT division.

\subsection{Cronbach's alpha test of reliability}

Table 5: Alpha coefficients for the four themes and their average inter-item correlation

\begin{tabular}{|l|l|l|}
\hline Investigative themes & Reliability (Alpha coefficient results) & Mean \\
\hline Section A: Factors impacting the development of products & 0.622 & 3.36 \\
\hline Section B: Change management's impact on product development & 0.791 & 3.33 \\
\hline Section C: Product development's impact on customer experience & 0.773 & 3.30 \\
\hline Section D: Project management's impact on product development & 0.872 & 3.36 \\
\hline
\end{tabular}

These are the Cronbach's alpha coefficient results for the four themes and their average inter-item correlation: the Cronbach's alpha for section A, questions 1 to 8 , was 0.70 for the first theme, which suggests that reliability is not as strong as was hoped for. However, for the remaining sections (B to $D)$, an above $70 \%$ reliability was established.

\section{DISCUSSION}

This study resides in the ICT sector, which is the underpinning force of economic and social change in the 21st century. Computers and associated computer devices with access to the internet have removed the distance barrier. Information systems (IS) support daily operations, and this support plays a huge role in product development. According to Nambisan [35], issues arise during the development of flexible IT architecture that supports network innovation models. This form of architecture enables access to innovative ideas from customers, and ensures IT platform support for inventors and organisations. It is very important that IT architecture is not built in isolation; ideally it should be integrated across the customer relationship management and financial systems. Integration of this sort creates an innovation pipeline that enable the management of customer needs. The common reasons behind product failure include the inability to adopt market positioning in product innovation, a dearth of market research, and omitting the customer from product development. Wig [24] mentions that a product is successful if it is profitable and if customers are satisfied with it. Customer satisfaction implies that customers will be faithful and will have an inclination to pay for the product or service. 
Based on the above analysis, a disparity among participants' perceptions is evident. It is recommended that the results of the findings from the survey questionnaire be provided as feedback for discussion in a management forum with as many of the participants as possible who took part in the survey, to establish more clearly the causal factors underlying the differing perceptions. This should then provide management with insight into what strategic actions could be initiated to achieve greater positive alignment.

\section{CONCLUSION}

Systems and procedures must be put in place to ensure that customers are more actively involved so that their needs are considered. An efficient change management tool should be adopted and integrated in the entire organisation. Change management training should be mandatory for every employee. All involved in the system and product environments should be adept in handling and planning change. A change champion should be allocated to each division to guide and motivate their peers, and to maintain stability by applying change as a natural socialised organisational lifestyle. A project manager should be allocated to manage the change to ensure divisional and customer priorities. Change is not an isolated event; and a project manager should ensure that the entire value chain is considered.

The high level of uncertainty in the responses suggests that there is a problem with the role of customer experience in product development. Apart from the customer being involved in the product development process, a customer experience official should be included as a core team member for every development. This function will ensure that the product fulfilment, assurance, and billing processes are customerfriendly. The organisation should adopt a single customer relationship management system for all customer needs. This can limit system issues and streamline the product development process, leaving the customer more satisfied. The organisation should consider applying the steps and principles of the strategic transformation programme management process and create a 'learning organisation' system. When a balanced scorecard system is combined with programme management, a foundation is laid for a learning organisation system that would enable management to integrate and coordinate all of the organisation's value chain processes [31].

\section{LIMITATIONS}

A restricted sample size in which the non-probability judgement sampling method has been used can lead to research findings that are not fully representative of the greater reality in ICT; therefore, caution needs to be exercised to prevent the research findings being generalised to all of the product houses.

\section{SUGGESTIONS FOR FUTURE RESEARCH}

More in-depth research is needed into the differences in perceptions and the impact of product development factors on customer experience across the different divisions of the product life cycle management process and functions of the customer experience office.

\section{REFERENCES}

[1] W. Liu, S. Ye and J. Moultrie, "Exploring traditional and new web-based methods to involve customers in new product development,” Int. J. Product Development, vol. 23, no. 1, pp.42-64, 2019.

[2] P. Steyn and E. Schmikl, Programme managing organisational performance and innovative improvement, Pretoria, Cranefield College of Project and Programme Management, 2013.

[3] A. Sannö and M. Ahlskog, "Integrating knowledge for manufacturing technology development," Int. J. Product Development, vol. 23, no. 1, pp.65-83, 2019.

[4] K. B. Clark and T. Fujimoto, Product development performance: Strategy, organization, and management in the world auto industry, Boston, Massachusetts, USA, Harvard Business School Press, 1991.

[5] E. W. Larson and C. F. Gray, Project management: The managerial process, New York, USA, McGraw-Hill/Irwin, 2011.

[6] A. Chyne, “Evolution of product development - Internet technology," 2016. [Online]. Available: https://www.quora.com/What-is-the-history-of-product-development-methodologies [Accessed Feb. 10, 2016].

[7] D. N. P. Murthy, M. Rausand and T. Østerås, Product reliability: Specification and performance, London, SpringerVerlag, 2008.

[8] G. J. Amue and C. K. Adiele, "New product development and consumer innovative behaviour: An empirical validation study," European Journal of Business and Social Sciences, vol. 1, no. 6, pp.97-109, 2012. 
[9] V. Krishnan and K. T. Ulrich, “Product development decisions: A review of the literature," Management Science, vol. 47, no. 1, pp.1-21, 2001.

[10] L. L. Glessner and D. Gillis, "The knowledge product lifecycle and the strategic dashboard," Continuing Higher Education Review, vol. 76, pp.100-111, 2012.

[11] N. Bhuiyan, "A framework for successful new product development," Journal of Industrial Engineering and Management, vol. 4, no. 4, pp.746-770, 2011.

[12] Booz, Allen and Hamilton, New product management for the 1980s, New York, Booz, Allen \& Hamilton, 1982.

[13] P. Kotler and G. Armstrong, Principles of marketing, New Jersey, USA, Pearson Education, 2010.

[14] W. J. Kramer, B. Jenkins and R. S. Katz, The role of the information and communications technology sector in expanding economic opportunity. Cambridge, MA: Kennedy School of Government, Harvard University, 22, 1-45., 2007

[15] G. Celebic and D. L. Rendulic, Basic concepts of information and communication technology handbook, Zagreb, Open Society for Idea Exchange (ODRAZI), 2011.

[16] M. Kodama, Competing through ICT capability innovation, New York, Palgrave Macmillan. 2013.

[17] P. DesAutels, E. Salehi-Sangari, P. Berthon, T. Rabinovich and L. Pitt, "It is emergent: Five propositions on the relationship between creative consumers and technology," International Journal of Technology Marketing, vol. 9 , no. 1, pp.72-85, 2014.

[18] Detecon International GmbH, Next generation telco product lifecycle management: How to overcome complexity in product management by implementing best-practice PLM, Bonn, Germany, 2010.

[19] A. Gillwald, M. Moyo and C. Stork, "Understanding what is happening in ICT in South Africa: A supply- and demandside analysis of the ICT sector," Evidence for ICT Policy Action: Policy Paper 7, Research ICT Africa, 2012. Available: https://d1wqtxts1xzle7.cloudfront.net/60942742/Policy_Paper_7_-

_Understanding_what_is_happening_in_ICT_in_South_Africa20191018-69079-1ut8w16-with-cover-page-

v2.pdf?Expires=1637658329\&Signature=ek2QPZa24ufs TJO5xSEdPI8UwibUHqtLDyejfkEEguW8yAkbcvqeQQHmROTz 0N6EV9PKIU84GQVLS51wevg-L57ssDq55NFaeeq-

faOwwpFqFCo XUm7qfhFqm8NHQd40QM1YolrgJMd9q 61ifWTd pg6JkEewsutcGRX0GotLta9clopPqZInDm35U YT5A EkhMz PNTBkh77xDXMe9gErhR5MnNNk4GFyxI EBNd8k4nYbQgkWPZ0ujwJM-r-t e2v-

HUplCHu3lD6VQfirfFUhunTvgmnqOIK3QWGvitvLdJkJ7x1BQcP8t kVRxlpwa4pappfcZuKoFvdi6A_\&Key-PairId=APKAJLOHF5GGSLRBV4ZA

[20] I. J. Syeda, "The reasons behind failure of new products," 2013. [Online]. Available: http://omanobserver.om/thereasons-behind-failure-of-new-products/ [Accessed Jan. 20, 2015].

[21] P. Grabowski, "7 reasons new products fail," 2016. [Online]. https://community.uservoice.com/blog/whyproducts-fail/ [Accessed Dec. 20, 2016].

[22] C. Loch and S. Kavadias, Handbook of new product development management, Burlington, ButterworthHeinemann, 2008.

[23] T. Berry, "Product and brand failures: A marketing perspective," 2010. [Online]. Available: http://www.mplans.com/articles/product-and-brand-failures-a-marketing-perspective/ [Accessed Jul. 20, 2015].

[24] C. Wig, "Six critical success factors for product development," 2010. [Online]. Available: http://christianwig.com/bizblog/2010/12/6-csf-for-product-development/ [Accessed Jan. 20, 2015].

[25] C. White, A. J. McMurray and P. Rudito, "Using mature concepts to generate new ideas: Technology acceptance revisited," International Journal of Technology Marketing, vol. 7, no. 4, pp.361-378, 2012.

[26] C. Figliomeni, Change management process for information technology, USA, Xlibris Corporation, 2012.

[27] Tata Consultancy Services, Change management theories and methodologies, Tata Consultancy Services Limited, 2013.

[28] Management Learning Center. Defining change management: Helping others understand change management in relation to project management and organizational change, Fort Collins, Prosci, 2007.

[29] J. Hayes, The theory and practice of change management, Basingstoke, Hampshire, Palgrave Macmillan, 2014.

[30] O. Passenheim, Change management, Denmark, Bookboon, 2010. Available:

https: / / books.google.co.za/books?hl=en\&lr=\&id=GoyWODjqDj4C\&oi=fnd\&pg=PA12\&dq=0.+Passenheim, +Change+ management,+Denmark++,+Bookboon,+2010\&ots=UXGQc3oCR6\&sig=oU8u_LHIHxJVQx9pbdD7smuYG0M\#v=onepag e\&q\&f $=$ false

[31] M. Hammer, Business process change management, Berlin, Springer-Verlag, 2003.

[32] J. Stark, Product lifecycle management (Volume 2): The devil is in the details, Switzerland, Springer International Publishing, 2016.

[33] R. Gagnon, "Effective change management: The five critical steps", 2013. [Online]. Available: http://www.huffingtonpost.com/ray-gagnon/effective-change-anageme_b_2993527.htmlv [Accessed Jul. 20, 2015].

[34] A. Immonen and A. Saaksvuori, Product lifecycle management, Berlin, Springer-Verlag, 2004.

[35] S. Nambisan, Information technology and product development, Pittsburgh, Springer Science \& Business Media, 2010.

[36] J. D. Stoneburner, “Project management methods for accelerated product development," 1999, unpublished. Available: https: //citeseerx.ist.psu.edu/viewdoc/download?doi=10.1.1.196.5174\&rep=rep1\&type=pdf

[37] J. A. Watkins, Theses/dissertation/research reports: A practical guide for researchers to the preparation of written presentations of academic research, Cape Town, SA, Lavender Moon Publishing, 2016.

[38] C. R. Kothari, Research methodology: Methods and techniques, New Delhi, New Age International, 2004. 